\title{
The Investigation of Obligatory Bail Contract from the Perspective of General and Particular Law Scholars
}

\author{
Zohreh Daraei $^{1}$ \\ ${ }^{1}$ Islamic Azad University, Ilam, Iran \\ Correspondence: Zohreh Daraei, Islamic Azad University, Ilam, Iran.
}

Received: September 4, 2016

Accepted: October 2, 2016 Online Published: December 29, 2016

doi:10.5539/jpl.v10n1p26

URL: http://dx.doi.org/10.5539/jpl.v10n1p26

\begin{abstract}
Bail is an important element of legal jurisprudence that its establishment has a long history. The scope of this contract is to the extent that is seen in almost all civil, criminal, commercial, intellectual and political matters. This legal institution today as one of the most common supporting arrangements is used for both private contracts and the judicial authorities. Due to the realization of this contract, the bailsman will be required to fulfill promised obligations. Obligatory bail includes those cases that cause the contracts lost the legal and contractual aspects and takes ruling and obligatory role. The necessity of this discussion arises from the need that the perpetrators of various crimes that in some cases encounter arresting and imprisonment escape in different ways and are excluded from the scope of justice and law enforcement. Since committing any crime has its own punishment, whether in the second case, another person that escaped wrongdoer is considered the same punishment or other legal actions will be with him? In this study, we investigate the causes and principles of this sentence.
\end{abstract}

Keywords: bail, obligatory bail, bailsman, pledged, obligee, attorney

\section{Introduction}

Bail contract is correct for us (Emamie Scholars) and it is correct for most of Sunat jurists, too but some of their jurists said that it is not true. Sheikh Tusi in Khalaf $\left(16^{\text {th }}\right.$ issue of Zamam $)$ has narrated all of their ideas. Bailment is today one of the chapters of legal jurisprudence that in courts widely used and arises criminal and civil litigations. Bailment can be investigated from various aspects of the conditions, rules and forms. One of the topics that has been less discussed is obligatory bail, in the event, this type of bailment is that the use of force and domination it will create legal effects on bailsman, pledged, obligee, the judiciary and others involved in.

Bail is a contract whereby the parties agree summon of third party. Committed person is called bailsman, and other third party is called pledged and the other party is called obligee. Or bailment is that a person committed when the creditor calls the debtor, the committed person (bailsman) gives the debtor to him in which he is called bailsman. Bail is true in which although is not expressed in Arabic in any verbal or practical way says to creditor that "I am committed whenever you ask the debtor I give him to you and creditor agrees". Bailsman must be responsible and wise and he should not force to do the bailment and he can summon the pledged. Although bail contract in civil matters is less used, but from the criminal point of view bailment is one of the subject of Article 132 of the Criminal Procedure Code. The judge is obliged to charge one of the arrangements of Article 132 of that law issue for access to accused person.

Literally meaning: bailment is a gerund and it means "to guarantee"

Common meaning: bail is actually a type of bond that common people call it a person's guarantee. This means that someone commits every time a person who is entitled to ask others to summon, he can summon him and maybe it is for financial rights such as debt or human rights. And bailment is a kind of contract that occurs between the bailsman and obligee [the owner]. Bail is derived from Kafal and means to undertake oneself to do something. In jurists' terms: "commitment to summon a person when claiming the right to obligee" In legal terms, "is a contract whereby one party agrees to summon third party against another party. Committed Person is called bailsman, the second party is called obligee and third party is called pledged"(Article 374 of the Civil Code). 


\subsection{The Nature of Bail}

At first, judicial authority takes provisional measures to arrest the bailsman in accordance with the law. This is essentially an act of justice and a judge at this stage with regard to the propriety of the importance of the offense, the accused records, age etc. and in the form of authoritarian and one-sided attempts to make legal determinations about the type and amount of committed funds.

\subsection{Obligatory Bailment}

Bail normally applies where someone agrees to summon a person by his will but in some cases, a person who has not committed to summon another person the law dictates that he must summon that person unless he oblige to pay his debts. In such cases, it is called obligatory bailment. Civil Code, Article 745 says: "Whoever withdraws a person under the authority of the other person without his consent is acting as the bailsman and he has to summon him, otherwise he must fulfill his debts. According to the above article, the commitment of bailsman does not have any contractual root, but the law puts it on his responsibility. That is why he is called "obligatory bailsman". To justify this responsibility, it can be said that as the bailsman thereby causing damage to others he should compensate the damage based on the " no harm principle ".So, crazy and stupid children are not immune from this responsibility and have to compensate for losses caused by their work (Article 1216 criminal law).

\subsection{Cases of Obligatory Bailment}

According to Article 745 whoever causes a person to escape and get out of the rightful owner, he is a bailsman. So the following persons are regarded bailsman:

1) While on duty, prison guard or officer who intentionally or due to negligence in the duty provided the freedom of pledged or a third party is responsible for that.

2) A person through deceit and individual teaching caused the pledged escaped. Should we be so sure that the stewardship sufficed or whether it should be considered an absolute obligatory bailment? The correct quote is that sponsorship should be considered absolute obligatory bailment.

3) Bailsman that accepted the bail due to the request of obligee then provided his release with the collusion or no collusion in such a way that creditor misses his right.

\section{Principles of Obligatory Bailment Responsibilities}

Obligatory bailment is against contractual bailment which in these cases that are described above cause the person to be known as a bailsman. In other words, it can be said that obligatory bailment causes are the causes of compulsory liability due to the similarities between sponsorship and liability in terms of waste, abuse, wastage confiscation and other issues that cause the responsibility of both. One of the provisions and rules that can be cited for being responsible in obligatory bailment is narrated from Imam Sadiq. "I asked Imam Sadiq that a person committed a murder. The judge ordered to deliver the murderer to the parents of victim for nemesis. At the time of execution, a group of people are raiding and rescuing the killer from the hands of the victim's parents. Imam said: in my opinion, liberators of the killer from the victim's parents should be arrested to hand over the killer. Then asked if the killer dies and they were still in prison? Imam said: If the murderer dies, they must pay blood money."

This narration is true about someone that escaped the killer in the case of obligation that released the killer from the hands of victim's parents and it has the role of bailsman from jurist's point of view in which he should be arrested or he should deliver the killer.

No harm account: Sahebe Javaher in the case of obligatory bailment responsibility says: Although there is no bailment in common meaning and the sponsorship of the bailsman is dedicated to creating sponsorship contract, but this does not prevent a person commits bail enforcement is absolved of responsibility but according to the rule of no harm and other reasons, this person should compensate the losses. In this case, there is no difference between the nerve, insane, and others, because these are referred to in losses compensation. In addition to the above, another narration that scholars cite the narrative in order to guarantee obligatory bailment is everyone illegally seizes the property of the others is sponsor until he returns it to its owner.

Implication of this story should be told that in such cases its mandate is general and does not have the financial rights; it guarantees all of the rights.

\subsection{Bailsman Responsibility in Criminal Matters and Non-Financial Crime}

Sometimes the bail is in connection with the murder, quasi-intentional and pure mistake. In each of these, if the 
person caused the pledged gets out of control of obligee it should not be sufficient to pay bail funds. Because firstly, when in religious rights purposes the primarily objective of the bail is receipt of property, imprisonment accepted. Then a fortiori that the purpose of bail in criminal matters is the individual, imprisonment will be accepted. Secondly, mass retaliation for murder including the cases in which bail would not be irreparable. Acting on the imprisonment of bailsman Makarem Shirazi says: "If the murderer had been sentenced to death, the trustee can be arrested until the murderer has been delivered. Acting on the imprisonment of bailsman for refusing to introduce pledged also says the Islamic tradition and religious words do not specify the time of imprisonment. According to the texts and fatwas this detention is unlimited, but three of those exceptions can be drawn:

A. It is proved that bailsman is really disabled to summon pledged

B. He accepted to pay the disputed right individually,

C. The secondary titles require that he remain in prison.

But in our opinion, first and second procedures are precedent. The new law does not talk about prison, which it needs to be investigated. "

In the case of bail in non-financial crimes, it can be referred to the crimes in the field of buying and selling drugs as well as crimes included in Article 188. In such crime if a person causes the release of these people, it should be said that although the financial terms of their bail fund guarantee is fairly large amounts and it is possible to collect bail funds, it seems that obligatory bailsman detention until the presence of person in court is worthy of it that they leave them because it leads to destruction and destabilize the security of community and for arresting accused persons the police spent demanding efforts. So it is necessary in the first stage of the sponsorship of this type of crime, difficult conditions are applied. And the release of such persons should not be done by cheap guarantees. And in the second phase for those who obstruct the implementation of the financial and non-financial penalties of these people, the prison sentence should be imposed. In such circumstances, the penalty is reduced. The document of this idea is the various traditions that were imported in the context of individual sponsorship. Amir Almomenin imprisoned a man who had custody of another man, and said to him: "find and bring your friend"(Ibn Babawayh, Vol. 3: 95). According to the owner of Riyadh, if the bailment is debt, judge can hold the bailsman as long as delivers the debtor, or pays the debt. But if payment on behalf of the bailsman is not possible, such as: Retribution and the parity that is punishable by Hadd or punishment, judge requires him to deliver the pledged. And if summoning of pledged is not possible but he has a substitute, such as murder retaliation, it will be sufficient to pay property than summoning the pledged.

\subsection{Bailment in Financial Matters}

What is understood from the traditions with regard to bailment indicate that the bail is only allocated to non-financial cases, but it turns out that these traditions are not specific to non-financial matters, because many of the crimes that are non-financial aspects and divine right are considered quorums and gets of the bailment scope. This does not seem to be just fine for most of the crime use money, because most crimes are not compensated with money. Regarding obligatory bailment it can be said that oblige can arrest the bailsman in which he is the cause of pledged release till he delivers the pledged or pays the bail funds. Of course this condition is the good one, but if the act is committed in a manner that causes harassment to the police or whether the entry is raped, it can be said that in addition to the amount specified in the contract bail bailsman should be responsible for incurred damages or penalties.

\subsection{Imprisonment of Bailsman in Financial Matters}

If obligee wants bailsman to summon pledged and pledged does not do the request of obligee whether the bailsman imprisons till the paying of bails funds or the will be just fine? There are the correct narratives that when bailsman refrains from handing over pledged, the judge jails him. Shiite clerics have issued to this matter, including the Shahidin, Sheikh Tusi, Sheikh Saduq, Mohaghegh Helli, Hilli, Sellar Deilami and others. Among the traditions mentioned above, only one hadith (inDaamo-Islam) bailsman should free up acting between summoning the pledged or he will personally pay the bail funds. In these narratives, imprisonment of bailsman stated correctly, so there is a contradiction between this tradition and other traditions that can be carried on according to the Daem tradition on the basis self-selection. Imam Sadiq (peace be upon him) as saying: If anyone takes the bailment of a person for a certain period of time and then specified time came and creditor asked his bail funds, in this case the sponsor is imprisoned, unless if pledged known, on his behalf bailsman has to pay his debts. And he can get it from him and if pledged is unknown, as if there is no choice but bailsman should pay it unless he dies and in this case, he is not responsible. 


\section{The Investigation of Obligatory Bail Contract from the Perspective of General and Particular Law Scholars}

In Vasael Alshie, there are four traditions in which Imam Ali( peace be upon him) imprisons a bailsman until he summons the pledged Shia scholars have referred to the traditions mentioned above. They order on bailsman in which refrains from handing over pledged, would have issued to prison him that: judge can jail the bailsman until can he summons the pledged or pays his debts. If there is the possibility of doing right by him, such as debt, but if not possible, such as parity or claim of retaliation or that Hadd or punishment, bailsman obliges to deliver pledged and the judge can also punish him for summoning pledged. About someone who can afford to pay the right, but refuses the current sentence is true. But if the bailsman fails to deliver pledged, if the claimed right has a substitute, such as the blood money in the murder even if it is unintentional, he should pay the substitute. When obligee requires the bailsman to deliver the pledged, he should deliver him even if he can pay the bail funds. The meaning of bailment is not limited to fulfilling the right, this a strong idea and if we assume that it is financial and it is paid by bailsman. If he paid it by the request of pledged, he can refer to pledged and takes it back and also he paid without the pledged request and he cannot visit the pledged. In these two cases, he can refer to pledged and takes the bail funds back; otherwise, he can't. Sheikh Saduq said: "If anyone had a right over the other and you have custody of him, you have to fulfill the right and if you guarantee him by financial matter, it is your own responsibility to pay it. Sheikh Tusi has said: "Whoever else guarantees (bail) the body of a third party until a certain time and does not deliver him at the designated time, obligee can jail the bailsman until he delivers the pledged or fulfills the right. Sheikh Tusi said in Mabsot that releasing the bailsman is bound to deliver pledged and in the book "Khalaf" emphasized permanent imprisonment of bailsman. It seems that this applies only in cases of murder and macroeconomic corruption. He says in Mabsot " if someone bails a person against the third party due to the indebted right, obligee can ask him to deliver pledged and if he delivers him, the pledge is fulfilled; otherwise, he should be jailed until delivering the pledged. Allame Heli said in Tazkeratol Foghaha that if bailment has long period and the time of the bailment is coming, if the pledged is present, it is the duty of bailsman to deliver the pledged. If the pledged is present and it is possible for bails man to bring him, he should go and bring him and if he cannot bring him without excuse, he should be jailed. He will not be arrested immediately. All scholars have given such a fatwa. But if he is sometimes present and sometimes absent meaning that their place is not clear and there is no news regarding them,the bailsman is not obliged to summon them. Because it is not possible and everything is not in their responsibility. Because he has not bailed the property. Owner of Meftah ol Keramah after quoting of Allameh Helli has said : Just like it is said in Nahayah,Saraer,Sharaeh Ol Islam, Almokhtasar ol mafeh, Tahrir ol ahkam, Irshad, Lama and AL rodhah al bahyah, the appearance of the expressins in this book is that if they pay what they were obliged to , the obligee must accept it and the bailsman will be exempted and it is written in tazkerat ol foghahah and Jameh ol maghased that if the obligee is not satisfied with paying the money, and demands their summoning, judge will make him surrender the pledged. Afterwards in explaining the statement of allameh Helli in qavaed ol ahkam it is said : Using the bailing, it is obligatory to summon the pledged, so if he did not submit them, they will be imprisoned and nothing else. in the Mavared Oh sejn it is stated that if bailsman does not submit the pledged, judge makes him to do so and if he declined, the obligee can ask the judge for his imprisonment until he summons the debtor or pay what he is obliged to. of course that is the case if the payment of money is possible for him, like paying the debts. Saheb Jawahir Ol Ahkam , under the statements of Mohaqeq Helli, has said: there is no problem and wrongdoing in that obligees can demand the debt from bailsman immediately, even if their bail is absolute, immediate and without expiration date. and if the bail has expiration time, after expiration, they can demand it. So if they rendered it completely, so that the owner of the right had access to it , their obligation is removed from what they are responsible for. If the bailsman declined it they can imprison them, also they can punish them so that they summon them, or they pay what they must , just like it is mentioned in Nahayeh Shekh Toosi, Saraer of Ibn Toosi, Mokhtasar ol manafeh of Mohaqeq Helli, Tahrir of Allameh Helli, Irshad , Monsef and Al Roudhaht Ol Bahiah.

\subsection{Religious Jurisprudence View Regarding Selection of the Bailsman between the Pledged's Summoning and Paying the Bails Funds}

The question here is that whether bailsmen have freewill in paying their debts or summoning the pledged? Tabasi says: " In the previous traditions it is said that selection is allowed between summoning the pledged and paying the bail funds. But this is not in any narratives except the ones of daaem O'l Islam. The reason is that sometimes the pledged have some objectives which is not of paying the money kind or they do not seek the objective from anyone other than the pledged if the guarantee is not about the property. Or else if the guarantee is given to the property, there is no doubt that guarantee is removed if by paying the debt by the bailsman just like when the 
pledged pays the debt or obligees are exempted or the pledged dies or the obligees are exempted from guarantee. As a result there is no place for this problem. Moreover there is a possibility that the narrative is about the most cases in which the bailsman does not pay the money, just like the case in Meftah ol Karameh.

\subsection{Legal View Regarding Selection of the Bailsman between the Pledged's Summoning and Paying the Bails Funds}

It is obvious that the security of confiscating and the cost of guarantee and necessity will be taken $\mathrm{Y}$ but we must see that these cases are under which rules and must be done by which authority ; civil or penal rules? Right now in Iran courthouses this issue is ambiguous just like some other ones and each judge obeys the rule based on his own inference and preference. Some consider this issue under the civil rules and some other under the penal ones. There is no doubt that the main reason of this is the problem in regulations; since the rule anticipated some issue but did not talk about how to deal with it. Perhaps most legal officials believe that taking the security and getting the bail funds and necessity funds must be done by civil laws and based on them. But there are some problems with this view that will be addressed later.

\section{Conclusion}

We can conclude from the issues in this research:

The nature of guarantee in penal and civil issues is the same and except in cases in which there is a specific law, the civil law rules over the relations between bailsmen and defendant with oblige (the public official). Of course, we must add that the interpretation of being allowed of guarantee contract in penal issues from the viewpoint of its supporters is not without negligence. The reason is that there is nothing necessary for canceling the allowed contract and this can be done without any formalities. While cancelling the security in the penal law is done via the positive action, in the correction of this view we must say that being allowed of the contract is the ability of its cancelling. This means that the person who pays the security can cancel his contract by surrendering the pledged. In this credit, we can allow the contract to the person paying the security. But the answer to the first question must be sought in the objective of security contract and its legal nature. In other words the main root of the answer must be sought in the important issue that whether the guarantee contract depends on proving the existence of debt for pledged or whether the existence of this claim results in disregarding the result of judgment .In the answer we must say that if the guarantee is some kind of getting the security, obviously, expressing that the obligee has no right shows that the guarantee was null from the beginning. But whenever the security is summoning the debtor and under the personal securities, undoubtedly, the proving of exemption of pledged results in the end of dispute and the end of guarantee and exemption of the bailsman. But the guarantee is not nullified. The result of the dispute that is the answer to our question comes to light when a bailsman accepts the summoning of the claimant with the specific necessity funds and does not keep his promise and states to the courthouse that the pledged was not indebted. In this case must the bailsman pay the necessity fund or be exempted with the proof of exemption of the pledged?

In answering this, it must be said that in spite of civil issues, in penal issues the guarantee is summoning the alleged so that his absence does not postpone the judgment. So just like it is understood from the article 140 of public and Enqelab courthouses regulations in the penal issues, if the alleged is not present when the court states, the bailsman must pay the security and we mustn't wait for the result of judgment.

\section{References}

Babawayh ibn Muhammad ibn Ali. (1413). Man La Yahzarh al-Faqih, Qom, al ALALAM school.

Boroujerdi, A. T. (1429). Shiite Feghh sources, Translation: Mehdi Hossenian Qomi and others (1st ed.). Tehran, Farhang Sabaz.

Helli, Fakhr al-Din Abi Talib, Muhammad (Fakhr al-Muhaqqiqīn).1389.ayzah Alfvayd Fi Alsharh Alghavaed, Volume II, Qom, By.cha, p. 80.

Helli. (1427).Tazkerate Alfoqaha' (publication of the Institute for al-Bayt (AS) vol. 15, p. 5.

Hurr Ameli, Mohammed bin Hsn.Vasaelo Alshiae, Volume XIII, Beirut, Dar al-Arabi revival Altras, no cha, the third, S153-151.

Hussein Ameli, S. M. J. (Bi ta).mftah Al Karama fi as Allamh, Volume V, al-Bayt Institute Lahya' Altras, S350-349-348.

Imam Khomeini. (1368).Tahrir Alvasileh(1st ed., Vol. 3). translated by Ali Eslami. Islamic Publications Office, p. 67. 
Katoziyan, N. et al. (1382). Certain contracts (4), (contracts Azny, Vsyqh $\neg$ Hay religion), second edition, p. 445.

Koleini, M. Y. I. (1407).Alkafi (4th ed.). Tehran, Dralktb Alaslamyh.

Langroodi Jafari, M. J. (1378).Bailment contract(3rd ed.). Tehran, Library Treasure of Knowledge, S50-20.

Makarem Shirazi, N. et al. (1427).New issues (2nd ed.). Qom, school publications Imam Ali bin Abi Talib (AS).

Najafi, M. (n.d.) .Javahr al-Kalam fi Alsharh al-Islam (Tehran: Daralktb Islamiyah, the sixth edition of 1394 AH) c 27, S348-347.

Najafi, M. H. (1404).jvahr al-Kalam fi Alsharhe Sharaye al-Islam, VII, Beirut, Dar Alehya Altoras al-Arabi.

Shirazi, N. M. (1428). Women sentences (Palmer), in one volume, published by the school of Imam Ali bin Abi Talib (PBUH), Qom, Iran, XI.

Tabassi, N. et al. (1411).Mavardalsejan Fi Alnosos Alfatawi.Qom, ALALAM school of Islam.

Tabatabaei, S. A. M. (1300).Ryaz Almasael fi al-Shara.Tehran, Almknyh Alaslamyh.

Torkamany, M., \&Kalantari, M. (Bita). A collection of the Advisory Legal Department of the Ministry of Justice, p. 459.

Tusi, M. (n.d.). Almabsot (Maktabh Almortzvih Lahya’ Alasar Al-Jaafaria) 265 J2.s.

Tusi, M. et al. (1427).Alkhlaf, al Altabh Aljamah Almodresin, Qom.

\section{Copyrights}

Copyright for this articleis retained by the author(s), with first publication rights granted to the journal.

This is an open-access article distributed under the terms and conditions of the CreativeCommons Attribution license (http://creativecommons.org/licenses/by/3.0/). 